\title{
Terrain characterization of small island using publicly available data and open- source software: a case study of Marinduque, Philippines
}

\author{
Arnold R. Salvacion ${ }^{1}$ (I)
}

Received: 16 January 2016/ Accepted: 29 January 2016/Published online: 15 February 2016

(C) Springer International Publishing Switzerland 2016

\begin{abstract}
Digital terrain attributes derived from digital elevation model (DEM) such as elevation, slope, and aspect are widely used to determine the influence of topography on different environmental and human processes. The advent of publicly available DEM data has provided a cheaper, low-cost alternative to traditional field data collection and survey. Handling, processing, and visualization of such data on an open-source software will provide researchers and specialists a better and faster way of generating digital terrain maps and creating input data for other analyses. This paper demonstrates the methodology of combining the use ASTER GDEM and SAGA functionality of QGIS, and R software to develop terrain maps for Marinduque, an island province of the Philippines.
\end{abstract}

Keywords Terrain mapping - Open-source $\cdot$ ASTER GDEM · QGIS · R software · Marinduque · Philippines

\section{Introduction}

\section{Digital terrain analysis}

According to Hutchinson and Gallant (2000) terrain plays an important role in regulating earth surface and atmospheric process. Understanding the nature of terrain can provide knowledge on nature and magnitude of these processes

Arnold R. Salvacion

arsalvacion@up.edu.ph

1 Department of Community and Environmental Resource Planning, College of Human Ecology, University of the Philippines Los Baños, College 4031, Laguna, Philippines through topographic analysis and visualization (Wilson 2012). Digital terrain analysis (DTA) is the science of quantitative land-surface analysis that deals with the collection, analysis, evaluation, and interpretation of geographical information of terrain's natural and artificial features (Zhou and Zhu 2013). The analysis involves derivation of terrain attributes from digital elevation data (Wilson 2012; Zhou and Zhu 2013). Common terrain attributes include elevation, slope, aspect, profile curvature, and topographic wetness index (Kemp et al. 2008; Wilson 2012; Zhang et al. 2012; Pakoksung and Takagi 2015). These terrain attributes are used to describe the morphology of the landscape and predict the effect of the terrain on environmental or human processes (Zhou and Zhu 2013). According to Behrens et al. (2010) terrain attributes are widely used for digital soil mapping because relief is an important factor in soil formation. Bajat et al. (2011) showed how environmental factors (including elevation and slope) affect population change in Southern Serbia. Dragićević et al. (2015) provided a review on how elevation, aspect, slope, and other topographic index influence occurrence of landslide. Significance of different terrain attributes are discussed in details elsewhere (i.e., Wilson 2012).

\section{Digital elevation model}

A typical input data for DTA is the Digital Elevation Model (DEM) (Qiming et al. 2008; Wilson 2012; Cheng et al. 2012). According to Li et al. (2005), there are three ways to acquire data for DTA: (1) field surveying or direct measurement of terrain surface using total station and global positioning system (GPS); (2) cartographic digitization of existing topographic maps; and (3) use of stereo pairs of aerial (or space) images and photogrammetric instruments. Examples of space images derived DEM 
Fig. 1 Location map of Marinduque, Philippines

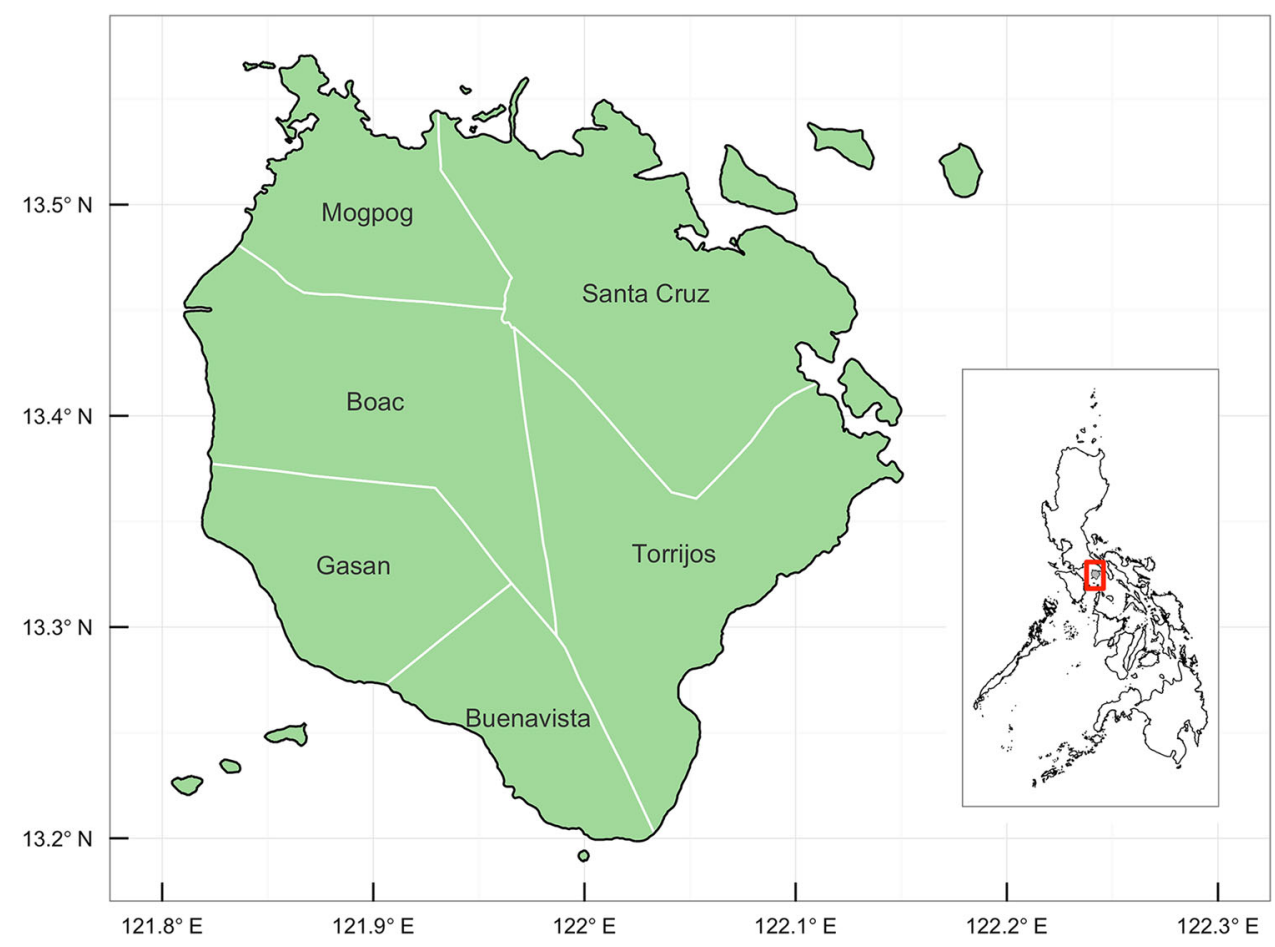

Table 1 Population and land area of six municipalities of Marinduque, Philippines (Data Source: NSCB 2015)

\begin{tabular}{llc}
\hline Municipality & Population (as of 2010) & Area (hectares) \\
\hline Boac (Capital) & 52,892 & 21,270 \\
Buenavista & 23,111 & 8,125 \\
Gasan & 33,402 & 10,088 \\
Mogpog & 33,384 & 10,806 \\
Sta. Cruz & 55,673 & 27,077 \\
Torrijos & 15,833 & 17,892 \\
\hline
\end{tabular}

include the shuttle radar topography mission (SRTM) (Farr et al. 2007) and advanced spaceborne thermal emission and reflection radiometer (ASTER) global digital elevation model (GDEM) (Abrams et al. 2015).

\section{ASTER GDEM}

According to Abrams et al. (Abrams et al. 2015), ASTER GDEM is the most up-to-date, complete, and high spatial resolution $(30 \mathrm{~m})$, digital topographic data set of the Earth
Fig. 2 Terrain mapping workflow

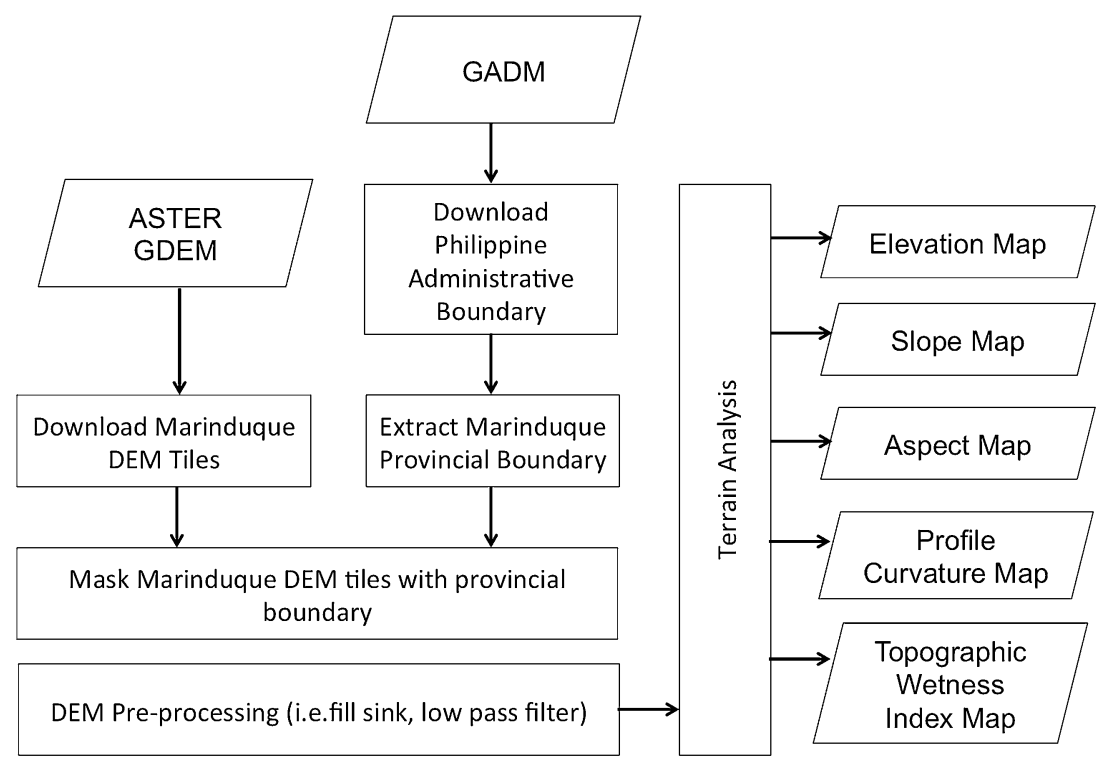


freely available (at no cost) to the public (Abrams et al. 2015). It is one of the many products of ASTER, a joint project between U.S. National Aeronautics and Space Administration (NASA) and Japan's Ministry of Economy, Trade, and Industry (METI). Operating on NASA's terra satellite, ASTER has been acquiring data (since March 2000) to produce other products such as the ASTER Emissivity Database (ASTER GED), the ASTER Global Urban Area Map (AGURAM), the ASTER Volcano Archive (AVA), ASTER Geoscience, and the Global Ice Monitoring from Space (GLIMS) (Abrams et al. 2015). Before the release of ASTER GDEM, SRTM was the most complete DEM data available to the public (Abrams et al. 2015). Several researches have utilized ASTER GDEM. Phillips et al. 2011 used terrain characteristic derived from ASTER GDEM along with WorldView imagery and fuzzy logic to model distribution of moulins in Sermeq Avannarleq in West Greenland. Gichamo et al. (2012) extract cross section of Tisza River in Hungary from ASTER GDEM. Kassab et al. (2013) combine ASTER GDEM with other remote sensing products to produce glacial geomorphological map of the Dalijia Shan region in the northeastern Tibetan Plateau. Sar et al. (2015) use ASTER GDEM along with other geospatial data to map the risk of water-logging disaster in Keleghai river basin, India. Recently, Mokarram and Hojati (2015) suggested that ASTER DEM is superior over areal photographs in delineating drainage network.

\section{Quantum GIS}

Quantum GIS (QGIS) (http://www.qgis.org/en/site/index. $\mathrm{html}$ ) is a free, open-source, and user friendly GIS software
Fig. 3 Elevation a map and b distribution of elevation across Marinduque Province
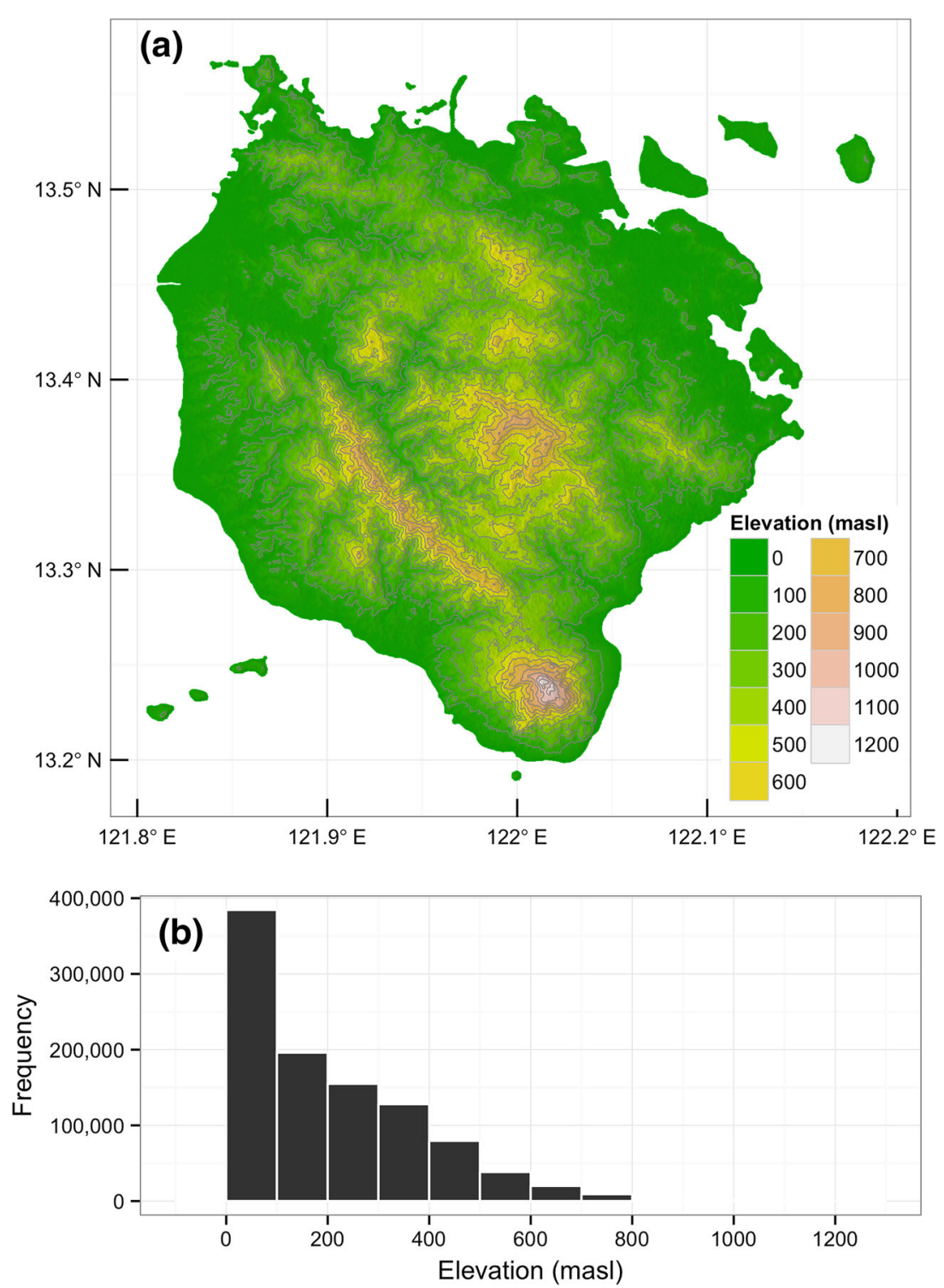
licensed under the GNU General Public License (http:// www.gnu.org/licenses/gpl-3.0.en.html) (Hugentobler 2008). The software is written $\mathrm{C}++$ and based on $\mathrm{C}++$ cross platform library enabling it to run on different operating systems such as Linux, Unix, Mac OS X and Windows (Hugentobler 2008). In addition, QGIS has a suite of terrain analysis functions from geographic resources analysis support system (GRASS) (Neteler and Mitasova 2008; Neteler et al. 2012) and system for automated geoscientific analyses (SAGA) GIS (Conrad et al. 2015). Furthermore, QGIS provides has a plug-in mechanism, which enables researchers and developers to extend the software functionality (Hugentobler 2008). Several researchers have adopted the use of QGIS on their study. Mantovani et al. (2010) combined QGIS with WebGIS to develop landslide geomorphological maps for the Olvera area in Cadiz, Spain. Yu et al. (2015) integrate QGIS with bayesian maximum entropy (BME) to map particulate matter concentration across Taiwan. Landuyt et al. (2015) mapped ecosystem services in Grote Nete basin in Belgium using QGIS.

\section{R software}

The R software is a free statistical computing and graphics environment that runs on wide variety of UNIX platforms, Windows and MacOS (Ihaka and Gentleman 1996; R Core Team 2014). Aside from statistical computing, $R$ also has a large number of contributed packages or libraries for handling, analyzing, and visualizing spatial data (Bivand et al. 2013). Packages such $s p$ (Bivand et al. 2013), rgdal (Bivand et al. 2014), maptools (Bivand and Lewin-Koh 2014), and raster (Hijmans 2014) are the common $R$ packages used to handle spatial data.
Fig. 4 Slope a map and b distribution of different slope class across Marinduque Province
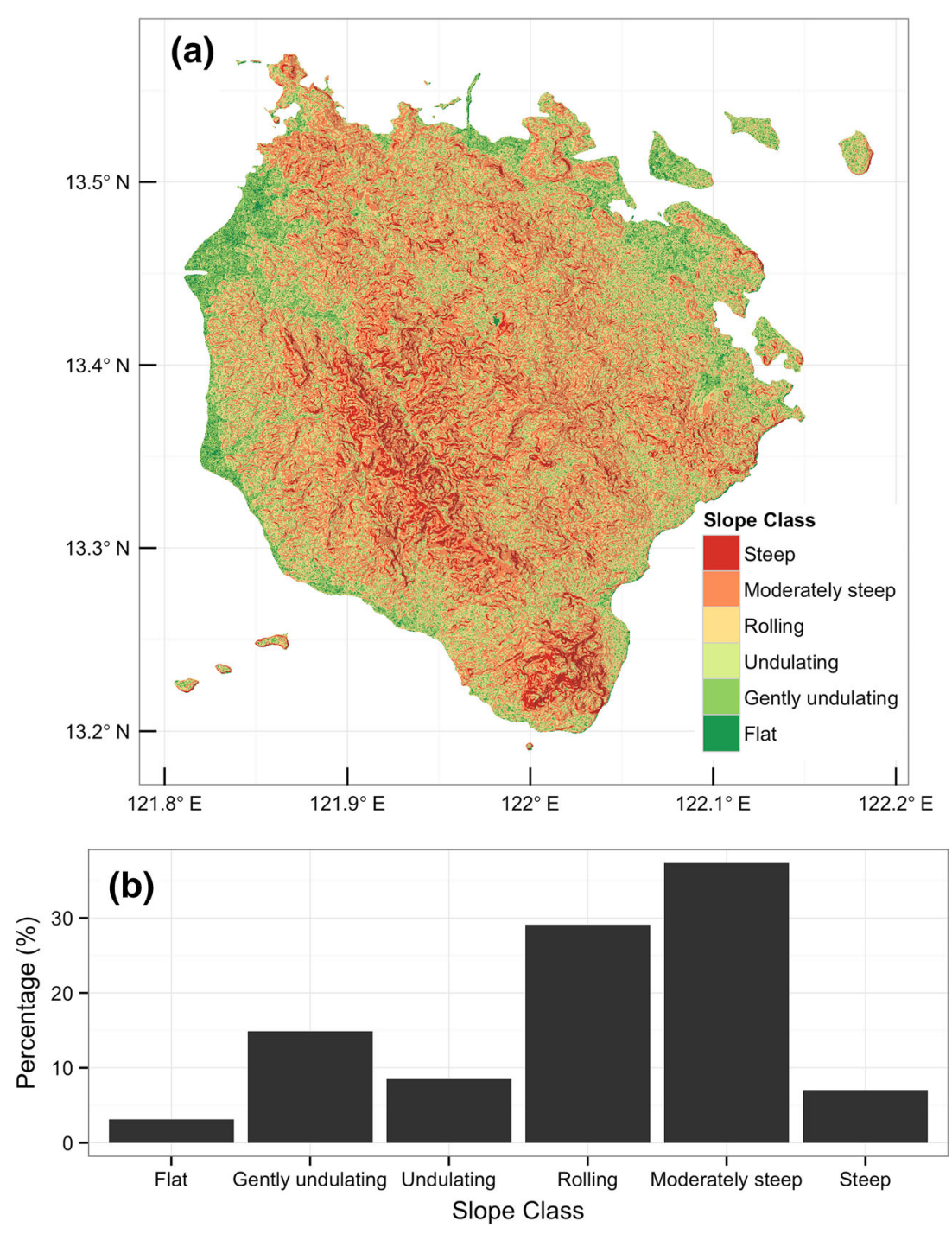


\section{Marinduque Island}

Marinduque is an island province of the Philippines situated around $200 \mathrm{~km}$ south of the country's capital (Manila) (Fig. 1). It is considered the heart of the Philippine archipelago because of its geometric shape and location (Salvacion and Magcale-Macandog 2015). There are six municipalities that consist the province covering around 96,000 hectares of land (Table 1).

\section{Methodology}

\section{Data}

Provincial boundary map of Marinduque was downloaded from Global Administrative Areas (www.gadm.org) through the getData function of the raster (Hijmans 2014) package in R. The GADM is a spatial database of the world's administrative areas, which include countries and lower subdivisions such as provinces, departments, bibhag, bundeslander, daerah istimewa, fivondronana, krong, landsvæðun, opština, sous-préfectures, counties, and thana (GADM 2015). Digital elevation data of Marinduque was downloaded from ASTER GDEM website (http://gdem. ersdac.jspacesystems.or.jp/).

\section{Processing and analysis}

The DEM data of Marinduque was downloaded manually from ASTER webpage while its provincial boundary was extracted from Philippine provincial administrative boundary downloaded from GADM website. Then, the DEM data was subjected to pre-processing (i.e., low-pass filter and pitremoval) prior to terrain analysis to remove any artifacts and depressions from the data. Next, different terrain (i.e., slope,
Fig. 5 Aspect a map and b distribution of different aspect class across Marinduque Province
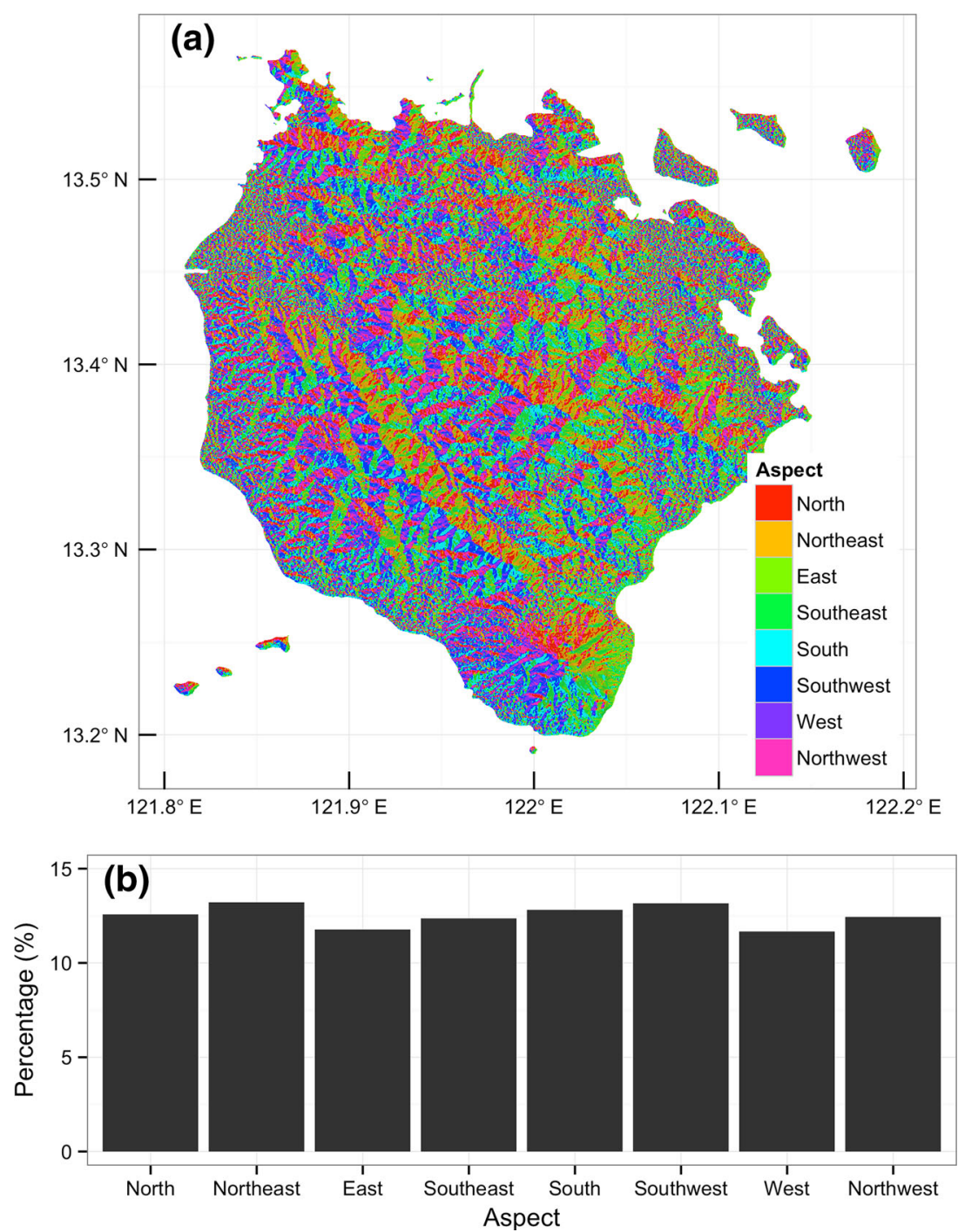
aspect, profile curvature, and topographic wetness index) characteristics were calculated from the processed DEM in QGIS. Figure 2 shows the schematic diagram used for terrain analysis. Further data analysis and visualization were using R (Ihaka and Gentleman 1996; R Core Team 2014) environment using the ggplot (Wickham 2009) and RColorBrewer (Neuwirth 2014) package.

\section{Results and discussion}

Elevation of the province ranges from 0 to $1187 \mathrm{~m}$ above sea level (masl) with an average elevation of 204 masl. Elevation map (Fig. 3a) of the province showed high elevation regions on its inner portion and low-lying areas on its outer part. Histogram of the elevation (Fig. 3b) reveals that majority of the island (93\%) is below 500 masl. Elevation information about an area is very important because of the altitudinal effect on precipitation and temperature, at higher elevation rainfall amount is higher while temperature is lower (Ishida and Kawashima 1993; Basist et al. 1994; Diaz and Bradley 1997; Sevruk 1997; Brunsdon et al. 2001; Qing et al. 2011). In addition, based on the study of Dragicević et al. (2015), risk of landslide susceptibility increases within the range of $250-750$ masl. In terms of slope, the province is dominated by rolling to moderately steep (approximately $66 \%$ ) slopes (Fig. 4a), which is distributed all over the area (Fig. 4b). Data on slope of an area is an indication of its vulnerability to different geohazards such as landslide and erosion, the steeper the area the higher is its risk (Balasubramani et al. 2015; Biswas and Pani 2015; Dutta et al. 2015; Pal 2015; Shit et al. 2015a, b; Dragićević et al. 2015; Chen et al. 2016). In fact, slope information is among the major input for different geohazard models (Lamelas et al. 2009; Cheng et al. 2013; Chen et al. 2016). On the other hand, aside
Fig. 6 Profile curvature a map and $\mathbf{b}$ distribution of different curvature class across Marinduque Province
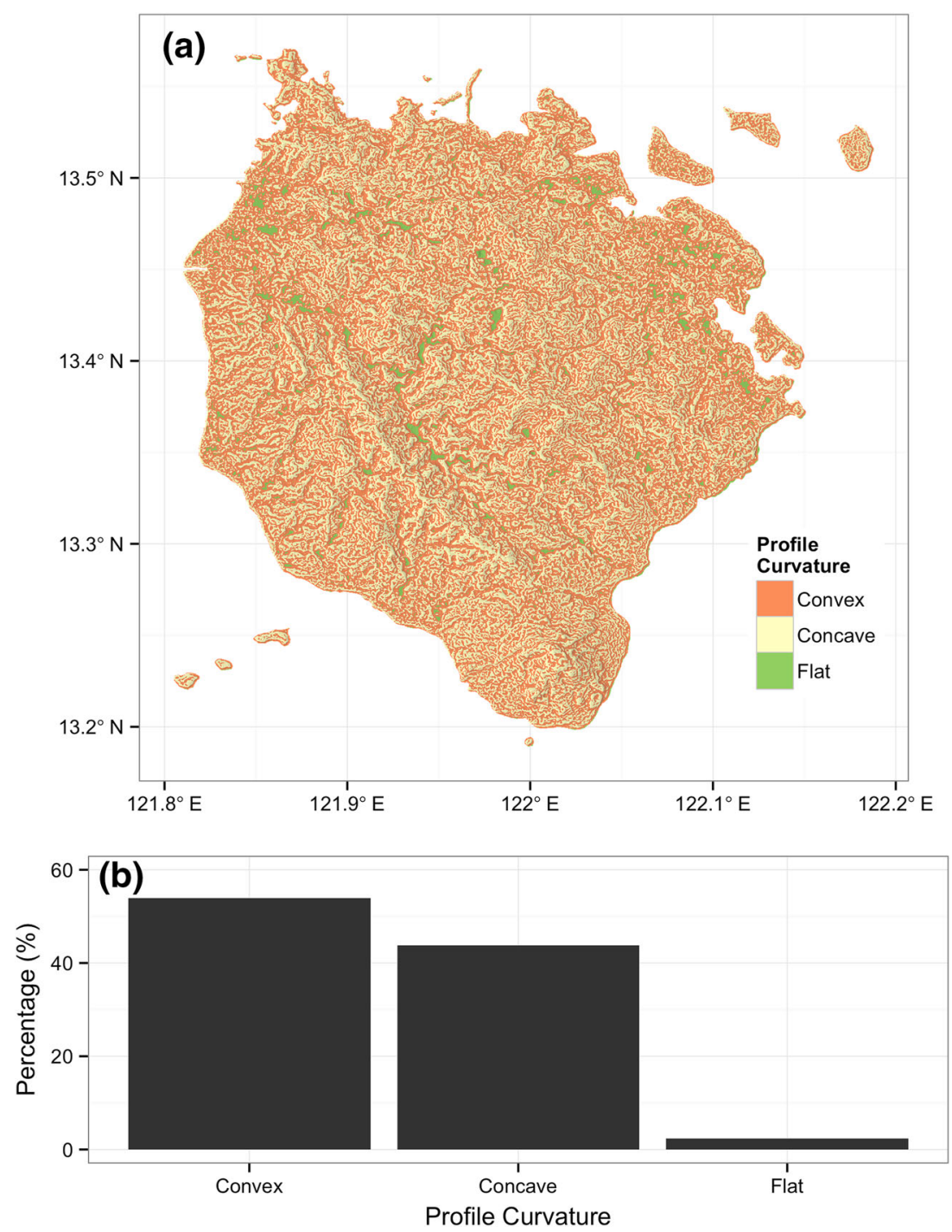
Fig. 7 Topographic wetness index $\mathbf{a}$ map and $\mathbf{b}$ distribution of topographic wetness across Marinduque Province
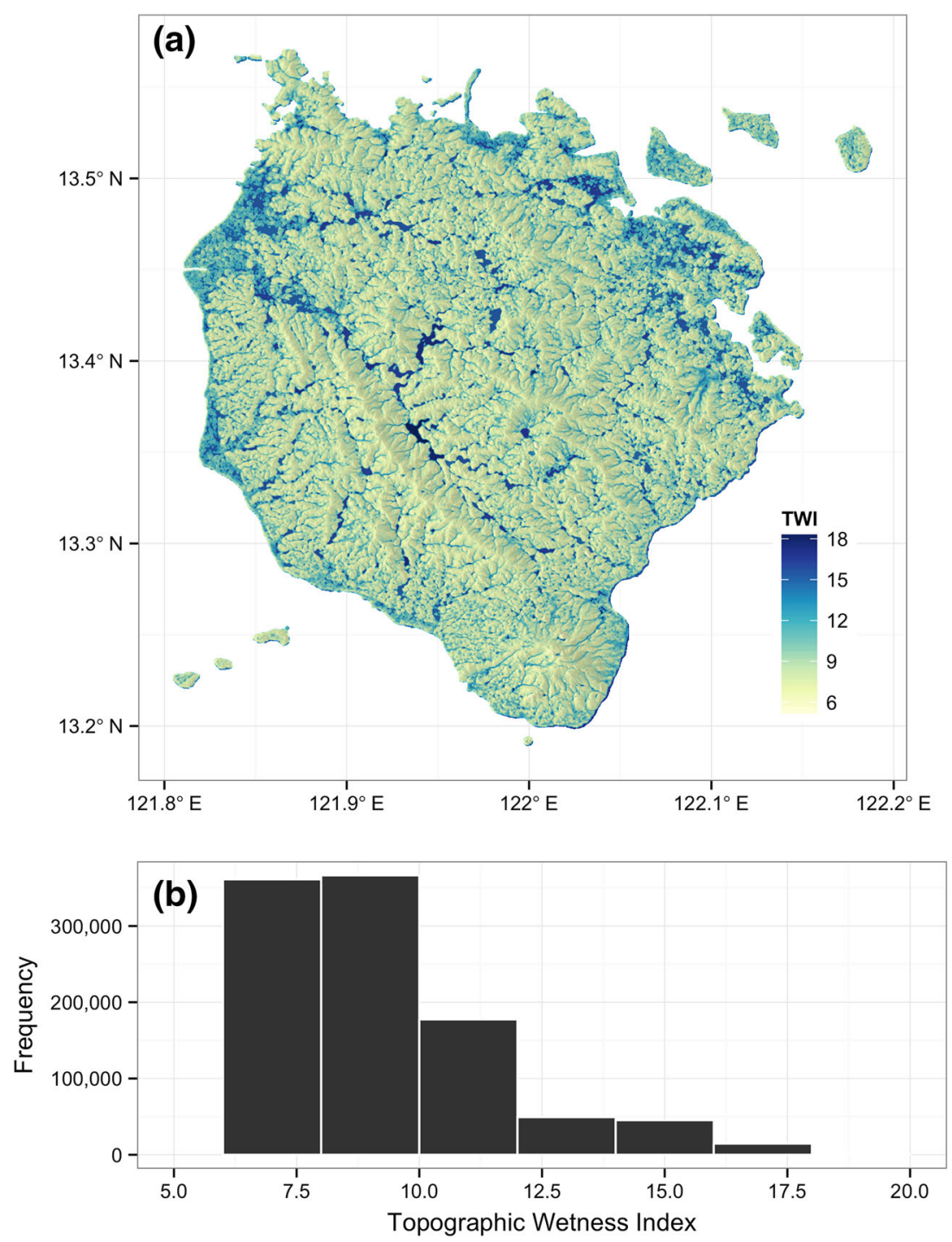

from slope angle, slope length and orientation (aspect) (Balasubramani et al. 2015; Biswas and Pani 2015; Dutta et al. 2015; Shit et al. 2015a; Xing et al. 2016). No distinct aspect class dominates the entire province. Based on the aspect map (Fig. 5a), the different aspect classes are distributed across the province (5b). According to Guan et al. (2013) aspect (slope orientation) is an important factor influencing solar radiation and air temperature of an area, a west-facing slope tends to have higher daily maximum temperature tan east-facing slope because daily maximum temperature occurs in the afternoon when the sun is in the west. Profile curvature map (Fig. 6a) of the province showed that the province is dominated by convex and concave profile (Fig. 6b). Profile curvature influence the velocity of flowing water in a surface affecting erosion and deposition (Alkhasawneh et al. 2013). Erosions were likely to occur under convex profile or deposition in the case of concave profile (Alkhasawneh et al. 2013). In terms of topographic wetness (Fig. 7a), low TWI values were calculated for most part of the province (Fig. 7b). The TWI can serve as index for surface saturation zones and spatial distribution of soil water, and quantify effect of topography on runoff (Qin et al. 2009). In the study of Zinko (2004) TWI was found to be positively correlated with ground water depth and soil $\mathrm{pH}$. The use of TWI varies from studying spatial scale effect of hydrological processes, geochemical, and biological processes (Hjerdt et al. 2004; Sørensen et al. 2006; Qin et al. 2009).

\section{Conclusion}

This paper demonstrated the use of publicly available DEM data from ASTER GDEM using open-source software (i.e., QGIS and R) for terrain mapping and characterization of a small island. These terrain maps can be used on different 
scientific application and research within the island (e.g., landform characterization, landslide mapping, etc.). In addition, the methodology from this paper can be replicated to other places or studies that require terrain information as inputs or reference data on their analysis.

\section{References}

Abrams M, Tsu H, Hulley G et al (2015) The advanced spaceborne thermal emission and reflection radiometer (ASTER) after fifteen years: review of global products. Int $\mathrm{J}$ Appl Earth Obs Geoinform 38:292-301. doi:10.1016/j.jag.2015.01.013

Alkhasawneh MS, Ngah UK, Tay LT et al (2013) Determination of important topographic factors for landslide mapping analysis using MLP network. Sci World J 2013:1-12. doi:10.1155/2013/ 415023

Bajat B, Hengl T, Kilibarda M, Krunić N (2011) Mapping population change index in Southern Serbia (1961-2027) as a function of environmental factors. Comput Environ Urban Syst 35:35-44. doi:10.1016/j.compenvurbsys.2010.09.005

Balasubramani K, Veena M, Kumaraswamy K, Saravanabavan V (2015) Estimation of soil erosion in a semi-arid watershed of Tamil Nadu (India) using revised universal soil loss equation (rusle) model through GIS. Model Earth Syst Environ 1:1-17. doi:10.1007/s40808-015-0015-4

Basist A, Bell GD, Meentemeyer V (1994) Statistical relationships between topography and precipitation patterns. J Clim 7:1305-1315. doi:10.1175/1520-0442(1994)007<1305: SRBTAP $>2.0 . \mathrm{CO} ; 2$

Behrens T, Zhu A-X, Schmidt K, Scholten T (2010) Multi-scale digital terrain analysis and feature selection for digital soil mapping. Geoderma 155:175-185. doi:10.1016/j.geoderma. 2009.07.010

Biswas SS, Pani P (2015) Estimation of soil erosion using RUSLE and GIS techniques: a case study of Barakar River basin, Jharkhand, India. Model Earth Syst Environ 1:1-13. doi:10. 1007/s40808-015-0040-3

Bivand R, Lewin-Koh N (2014) maptools: tools for reading and handling spatial objects

Bivand RS, Pebesma E, Gómez-Rubio V (2013) Applied spatial data analysis with R. Springer, New York

Bivand R, Keitt T, Rowlingson B (2014) rgdal: Bindings for the Geospatial Data Abstraction Library

Brunsdon C, McClatchey J, Unwin DJ (2001) Spatial variations in the average rainfall-altitude relationship in Great Britain: an approach using geographically weighted regression. Int J Climatol 21:455-466. doi:10.1002/joc.614

Chen X-L, Liu C-G, Chang Z-F, Zhou Q (2016) The relationship between the slope angle and the landslide size derived from limit equilibrium simulations. Geomorphology 253:547-550. doi:10. 1016/j.geomorph.2015.01.036

Cheng G, Liu L, Jing N et al (2012) General-purpose optimization methods for parallelization of digital terrain analysis based on cellular automata. Comput Geosci 45:57-67. doi:10.1016/j. cageo.2012.03.009

Cheng Y, Zhang J, Peng J (2013) ArcGIS-based evaluation of geohazards at Yaozhou County, Shaanxi, China. J Rock Mech Geotech Eng 5:330-334. doi:10.1016/j.jrmge.2012.11.002

Conrad O, Bechtel B, Bock M et al (2015) System for automated geoscientific analyses (SAGA) v. 2.1.4. Geosci Model Dev 8:1991-2007. doi:10.5194/gmd-8-1991-2015
Diaz H, Bradley R (1997) Temperature variations during the last century at high elevation sites. In: Diaz H, Beniston M, Bradley $\mathrm{R}$ (eds) Climatic change at high elevation sites. Springer, Netherlands, pp 21-47

Dragićević S, Lai T, Balram S (2015) GIS-based multicriteria evaluation with multiscale analysis to characterize urban landslide susceptibility in data-scarce environments. Habitat Int 45:114-125. doi:10.1016/j.habitatint.2014.06.031

Dutta D, Das S, Kundu A, Taj A (2015) Soil erosion risk assessment in Sanjal watershed, Jharkhand (India) using geo-informatics, RUSLE model and TRMM data. Model Earth Syst Environ 1:1-9. doi:10.1007/s40808-015-0034-1

Farr TG, Rosen PA, Caro E et al (2007) The shuttle radar topography mission. Rev Geophys. doi:10.1029/2005RG000183

Gichamo TZ, Popescu I, Jonoski A, Solomatine D (2012) River crosssection extraction from the ASTER global DEM for flood modeling. Environ Model Softw 31:37-46. doi:10.1016/j. envsoft.2011.12.003

Global Administrative Areas (GADM) (2015) GADM database of Global Administrative Areas. http://www.gadm.org/. Retrieved 30 Mar 2015

Guan H, Zhang X, Makhnin O, Sun Z (2013) Mapping mean monthly temperatures over a coastal hilly area incorporating terrain aspect effects. J Hydrometeorol 14:233-250. doi:10.1175/JHMD-12-014.1

Hijmans RJ (2014) raster: geographic data analysis and modeling. R package version 2.3-12

Hjerdt KN, McDonnell JJ, Seibert J, Rodhe A (2004) A new topographic index to quantify downslope controls on local drainage. Water Resour Res 40:1-6. doi:10.1029/ 2004WR003130

Hugentobler M (2008) Quantum GIS. Encyclopedia of GIS. Springer, New York, pp 935-939

Hutchinson MF, Gallant JC (2000) Digital elevation models and representation of terrain shape. In: Wilson JP, Gallant JC (eds) Terrain analysis. Principles and Applications, Wiley, pp 29-50

Ihaka R, Gentleman R (1996) R: a language for data analysis and graphics. J Comput Graph Stat 5:299-314. doi:10.1080/ 10618600.1996.10474713

Ishida T, Kawashima S (1993) Use of cokriging to estimate surface air temperature from elevation. Theor Appl Climatol 47:147-157. doi:10.1007/BF00867447

Kassab C, Wang J, Harbor J (2013) Glacial geomorphology of the Dalijia Shan region, northeastern Tibetan Plateau. J Maps 9:98-105. doi:10.1080/17445647.2012.754729

Kemp KK, Sage Publications., Sage eReference (Online service) (2008) Encyclopedia of geographic information science. SAGE Publications, Los Angeles

Lamelas MT, Hoppe A, de la Riva J, Marinoni O (2009) Modelling environmental variables for geohazards and georesources assessment to support sustainable land-use decisions in Zaragoza (Spain). GIS SDA Appl Geomorphol 111:88-103. doi:10.1016/j. geomorph.2008.10.021

Landuyt D, Van der Biest K, Broekx S et al (2015) A GIS plug-in for Bayesian belief networks: Towards a transparent software framework to assess and visualise uncertainties in ecosystem service mapping. Environ Model Softw 71:30-38. doi:10.1016/j. envsoft.2015.05.002

Li Z, Zhu Q, Gold C (2005) Digital terrain modeling: principles and methodology. CRC Press, New York

Mantovani F, Gracia FJ, de Cosmo PD, Suma A (2010) A new approach to landslide geomorphological mapping using the Open Source software in the Olvera area (Cadiz, Spain). Landslides 7:69-74. doi:10.1007/s10346-009-0181-4 
Mokarram M, Hojati M (2015) Comparis of digital elevation model (DEM) and aerial photographs for drainage. Model Earth Syst Environ 1:1-6. doi:10.1007/s40808-015-0050-1

National Statistical Coordination Board (NSCB) (2015) Philippine Standard Geographic Code. http://nap.psa.gov.ph/activestats/ psgc/province.. sp? provcode $=174000000 \&$ regCode $=17 \&$ regName $=$ REGION+IV-B+\%28MIMAROPA\%29. Accessed 24 Jan 2015

Neteler M, Mitasova H (2008) Open source GIS a GRASS GIS approach. Springer, New York

Neteler M, Bowman MH, Landa M, Metz M (2012) GRASS GIS: a multi-purpose open source GIS. Environ Model Softw 31:124-130. doi:10.1016/j.envsoft.2011.11.014

Neuwirth E (2014) RColorBrewer: ColorBrewer Palettes. R package version $1.1-2$

Pakoksung K, Takagi M (2015) Digital elevation models on accuracy validation and bias correction in vertical. Model Earth Syst Environ 2:1-13. doi:10.1007/s40808-015-0069-3

Pal S (2015) Identification of soil erosion vulnerable areas in Chandrabhaga river basin: a multi-criteria decision approach. Model Earth Syst Environ 2:1-11. doi:10.1007/s40808-0150052-z

Phillips T, Leyk S, Rajaram H et al (2011) Modeling moulin distribution on Sermeq Avannarleq glacier using ASTER and WorldView imagery and fuzzy set theory. Remote Sens Environ 115:2292-2301. doi:10.1016/j.rse.2011.04.029

Qiming Z, Lees B, Guo-an T (2008) Advances in digital terrain analysis: The TADTM initiative. In: Zhou Q, Lees B, Tang G (eds) Advances in digital terrain analysis. Springer, Berlin, pp 3-10

Qin C-Z, Zhu A-X, Pei T et al (2009) An approach to computing topographic wetness index based on maximum downslope gradient. Precis Agric 12:32-43. doi:10.1007/s11119-0099152-y

Qing Y, Zhu-Guo M, Liang C (2011) A preliminary analysis of the relationship between precipitation variation trends and altitude in China. Atmos Ocean Sci Lett 4:41-46. doi:10.1080/16742834. 2011.11446899

R Core Team (2014) R: A Language and Environment for Statistical Computing

Salvacion AR, Magcale-Macandog DB (2015) Spatial analysis of human population distribution and growth in Marinduque Island. J Mar Isl Cult, Philippines. doi:10.1016/j.imic.2015.06.003
Sar N, Chatterjee S, Das Adhikari M (2015) Integrated remote sensing and GIS based spatial modelling through analytical hierarchy process (AHP) for water logging hazard, vulnerability and risk assessment in Keleghai river basin, India. Model Earth Syst Environ 1:1-21. doi:10.1007/s40808-015-0039-9

Sevruk B (1997) Regional dependency of precipiation-altitude in the Swiss Alps. Clim Change 36:355-369. doi:10.1023/A: 1005302626066

Shit PK, Nandi AS, Bhunia GS (2015a) Soil erosion risk mapping using RUSLE model on Jhargram sub-division at West Bengal in India. Model Earth Syst Environ 1:1-12. doi:10.1007/s40808015-0032-3

Shit PK, Paira R, Bhunia G, Maiti R (2015b) Modeling of potential gully erosion hazard using geo-spatial technology at Garbheta block, West Bengal in India. Model Earth Syst Environ 1:1-16. doi:10.1007/s40808-015-0001-x

Sørensen R, Zinko U, Seibert J (2006) On the calculation of the topographic wetness index: evaluation of different methods based on field observations. Hydrol Earth Syst Sci 10:101-112. doi:10.5194/hess-10-101-2006

Wickham H (2009) ggplot2. Springer, New York

Wilson JP (2012) Digital terrain modeling. Geospatial Technol Geomorphol Mapp Proc 41st Annu Binghamt Geomorphol Symp 137:107-121

Xing W, Yang P, Ren S et al (2016) Slope length effects on processes of total nitrogen loss under simulated rainfall. CATENA 139:73-81. doi:10.1016/j.catena.2015.12.008

Yu H-L, Ku S-C, Kolovos A (2015) A GIS tool for spatiotemporal modeling under a knowledge synthesis framework. Stoch Environ Res Risk Assess 1-15. doi: 10.1007/s00477-015-1078-5

Zhang S, Huang Y, Shen C et al (2012) Spatial prediction of soil organic matter using terrain indices and categorical variables as auxiliary information. Geoderma 171-172:35-43. doi:10.1016/j. geoderma.2011.07.012

Zhou Q, Zhu A-X (2013) The recent advancement in digital terrain analysis and modeling. Int J Geogr Inf Sci 27:1269-1271. doi:10.1080/13658816.2013.794281

Zinko U (2004) Plants go with the flow - predicting spatial distribution of plant species in the boreal forest. $\mathrm{PhD}$ Thesis, Umea University 